\title{
LOCAL FOOD AND RENEWEABLE ENERGY AS EMERGING NEW ALTERNATIVES OF RURAL SUSTAINABILITY IN FINLAND
}

\author{
Marja Järvelä ${ }^{1}$, Pekka Jokinen ${ }^{2}$, Suvi Huttunen ${ }^{3}$, Antti Puupponen ${ }^{4}$
}

\begin{abstract}
The rurality of small Northern countries such as Finland has traditionally been based on family farm practices. However, rural sustainability is polarizing between the large-scale industrial agriculture and the more regional and multifunctional smallscale specialisations. This paper addresses small-scale entrepreneurship which aims at enhancing sustainable livelihood and sustainable development on farms. We identify two main lines of pioneering rural entrepreneurship in Finland, local food and renewable energy. Firstly, it is asked what kind of barriers and development targets these new productions are expected to have. Secondly, to what extent do they reflect real transformation as described particularly by the multifunctionality and ecological modernisation thinking? The two empirical case studies were carried out in Central Finland. We find that individual farms begin to identify the importance of mutual networking while establishing new businesses meeting the sustainability criteria. This certainly indicates social transformation. However, we also conclude that farmers in Central Finland seldom go for radical alternative productions imitating strong ecological modernisation.
\end{abstract}

Keywords: rural sustainability; local food production; renewable energy production; small scale entrepreneurship; farming and multifunctionality; Finland.

Tiivistelmä: Pohjoismaissa maaseutu on perinteisesti rakentunut perheviljelmäkäytännöille. Nykyisin maaseudun kehityskulku on kuitenkin polarisoitumassa teollisen maatalouden sekä pienimuotoisen ja erikoistuneen tuotannon välillä. Tämä artikkeli käsittelee maaseudun pienyrittäjyyttä, joka pyrkii edistämään kestävää toimeentuloa ja maatilojen kestävää kehitystä. Lähiruoka ja uusiutuva energia edustavat tutkimuksessamme edellä käyviä tuotantosuuntia. Selvitämme niiden näköpiirissä olevia esteitä ja kehityspolkuja. Tutkimme myös, missä määrin nämä uudet tuotantosuunnat heijastavat muutoksia, joista puhutaan esimerkiksi ekologisen modernisaation ja monivaikutteisen maatalouden yhteydessä. Empiirisesti artikkeli perustuu kahteen tapaustutkimukseen, jotka on tehty Keski-Suomessa. Päätuloksemme on, että käynnissä oleva maaseudun muutos näkyy erityisesti siten,

\footnotetext{
${ }^{1}$ Prof. Marja Järvelä, Department of Social Sciences and Philosophy, University of Jyväskylä, Mittilanniemi 1, 40014 Jyväskylä, e-mail: mjarvela@yfi.jyu.fi

${ }^{2}$ Prof. Pekka Jokinen, Natural Resource Policy, University of Joensuu, Tulliportinkatu 1, 80101 Joensuu, e-mail: pekka.jokinen@joensuu.fi

${ }^{3}$ Suvi Huttunen, Department of Social Sciences and Philosophy, University of Jyväskylä, Mittilanniemi 1, 40014 Jyväskylä, e-mail: suvi.m.huttunen@jyu.fi

${ }^{4}$ Antti Puupponen, Department of Social Sciences and Philosophy, University of Jyväskylä, Mittilanniemi 1, 40014 Jyväskylä, e-mail: anpuuppo@yfi.jyu.fi
} 
että viljelijät ovat alkaneet tunnistaa keskinäisen yhteistyön tärkeyden kestävän toimeentulon tavoittelussa. Toisaalta päättelemme, että viljelijöiden ratkaisut tuotantosuuntien valinnoissa eivät muistuta vahvan ekologisen modernisaation dynamiikkaa.

Avainsanat: maaseudun kestävyys; lähiruoka; uusiutuva energia; pienyrittäjyys; monivaikutteinen maatalous; Suomi

\section{Introduction}

Globalisation and climate change induce high pressure on the development of agriculture and agri-environmental systems. Food is increasingly transported around the world which increases emissions and pollution related to transport and packages (Lyons et al. 2004). Simultaneously, from the eco-efficiency perspective the huge input of energy (and particularly of fossil energy sources) in the globalising food system is becoming more questionable. Basically, a relocalisation of some production lines of food supply can strengthen the sustainability of both production and consumption (e.g. Morgan et al. 2006; Halkier et al. 2007; Fonte 2008). Yet, modern multifunctional farms are not reaching out for the enhanced eco-efficiency of food chain solely by saving energy. They also consider how to produce energy on farms either as a side product of their main production line or as a separate function yielding extra income. In technological terms, this is realistic by initiating energy crop production, for instance. The idea of modern renewable energy sources also fits the practice of on-farm energy production since these productions are diffuse by nature and the technologies are of a smaller scale (Elliott 2000; van Vliet 2000). Nevertheless, the farmers encounter many socio-economic and socio-cultural constraints currently hindering rural initiatives towards a more efficient use of renewable energy sources.

The rurality of small Northern countries such as Finland has traditionally been based on family farm practices but rural sustainability is increasingly polarizing between the large-scale industrial agriculture and the more regional and multifunctional small-scale specialisations (Tykkyläinen 2005). The rapid transition of the Finnish agricultural system towards bigger farms has been driven by economics of scale and it is related both to Finland's EU membership since 1995 and to the more general globalisation of agricultural markets (Niemi \& Ahlstedt 2008). A remarkable part of the traditional rural entrepreneurship seems to have vanished because the improved technological means and skills have led to specialisation and increase of efficiency. On the other hand, the cultural framework of family farming has remained the strong backbone of business continuity, especially for local food productions (Silvasti 2003). The Finnish farms are also basically pluriactive as forestry still is a central farming activity and most of the farms are carrying on both agriculture and forestry (Niemi \& Ahlstedt 2008).

This paper addresses pioneering small-scale entrepreneurship which aims at enhancing sustainable development on farms. The new designs for sustainable business can supposedly rely on a combination of agriculture and forestry or establish new individual farm specialisations. We have identified two main lines of pioneering rural entrepreneurship in Finland, namely local food and renewable energy. According to our view, both of them can contribute to rural sustainability and to the eco-efficiency of production and consumption chains. Furthermore, there may appear novel forms of agricultural multifunctionality partly guided by local heritage and partly exploring new combinations of technological and social innovations. Thus, what kind of barriers and development targets are these new productions expected to have according to local farmers and other stakeholders? To what extent do the new production activities reflect genuine transformation as described particularly by the concepts of multifunctionality and ecological modernisation? 
The two empirical case-studies ${ }^{5}$ focus on Central Finland ${ }^{6}$. In the local food case study ${ }^{7}$, indepth interviews have been made with 31 farmers. In order to put local food production and its multifunctional dimensions in a larger societal context, also 11 managers from local retails and 15 rural development managers working with local food projects have been interviewed. In the renewable energy case study ${ }^{8}$ data was collected by both in-depth interviews and observation. In total, 30 farmers producing energy were interviewed in their farms. The collection of data was inspired by ethnographic thinking as we tried to capture people's perceptions and action relevant to rural sustainability and farm livelihood. This involves the goal to understand farmers' experiences and local farming culture in their spatial context. In both cases, the results are based on qualitative thematic analysis which has meant identifying, firstly, the basic themes and organising themes in stories on local food and bioenergy, and, secondly, finding patterns of living and thinking. We use some direct quotes taken from the conversation data in order to illustrate the interpretations which have been made.

\section{Multifunctionality and agricultural transitions}

The many definitions of sustainable agriculture have allowed plenty of scope for various alternative agricultural methods of production to declare that they each promote sustainability. As a consequence, the legitimacy issue of sustainable agriculture has become more complex, with a stronger element of rural development which includes a social dimension and even a consumer society pressure for diversity, quality and security in food supply. Rural sustainability is often associated with multifunctionality at the production premises, which will

\footnotetext{
${ }^{5}$ The data belongs to an on-going study on small-scale rural entrepreneurship as an innovative pathway towards rural sustainability. The interviews have been carried out in $2002-2007$. All interviews have been transcribed verbatim in Finnish and the direct citations present in this article have been translated into English by the authors.

${ }^{6}$ Central Finland has approximately 260,000 inhabitants and its capital is Jyväskylä. As in whole Finland, the number of farms is decreasing but the average size of production units is increasing. At moment, there are about 3,600 active farms with an average field area of 29 hectares and an average forest area of 66 hectares per farm (Information Centre of the Ministry of Agriculture and Forestry in Finland). More than half of them is livestock farms and over third is dairy farms. Primary production contributes five per cent to the employment in the region corresponding with the average of the whole country. As comes to food industry in Central Finland, there are only ten companies employing more than 20 persons (Nieminen 2006). In addition, there are approximately 300 smaller firms with various food products (ibid.). It is estimated that the whole food chain employs 21,000 people in the region. The number of farmers producing energy is still rather limited in Finland. The majority of them are entrepreneurs and in 2006 there were about 200 heat entrepreneurs (Alanen 2007). The production of biogas or biodiesel occurs clearly in smaller numbers as there are around ten farms producing biogas and some $20-50$ farms producing biodiesel (Kuittinen et al. 2007).
} ${ }^{7}$ Antti Puupponen took the first contacts to farmers with the assistance of a particular project advancing regional local
food activities. Next, local food producers were selected with the snowball method and totally 11 female farmers and
20 male farmers in 27 farms were interviewed. The arable areas of these farms varied a lot, from 8 to 100 hectares,
and thus they represent small and medium-size as well as large Finnish farms. 19 farms practised conventional
production and eight were organic farms. There was also variation in the main products: they mainly covered
vegetables, herbs, beet, grain, and milk products. The interviews with rural development managers were started by
Puupponen with the help of a regional coordination project for food production. The selection of interviewees was
continued with the snowball method. Totally, in-depth interviews were made with nine female managers and six male
managers. Educational organisation was the most typical institutional background (e.g. a university of applied
sciences) of rural development managers; also some representatives of companies or NGO's were included in this
sample. All the local retailers, three females and eight males, worked for the one or the other of the two major
wholesale businesses dominating the Finnish market. The majority of them were shopkeepers; other positions
present in data were manager of unit and director of business. Differing from the in-depth interviews with individuals,
this section includes one group interview with three retailers.

\footnotetext{
${ }^{8} 15$ farmers Suvi Huttunen interviewed were heat entrepreneurs, 10 produced biogas and five produced biodiesel. Almost all the energy producers identified themselves as farmers as they were also producing food. There were only two exceptions: forestry was the main livelihood of the two heat entrepreneurs. Even if the majority of interviewees named food production as their main income source, there were also other jobs or enterprises in addition to the agricultural and energy production activities. The heat entrepreneurs were selected on the regional grounds: all heat entrepreneurs living in Central Finland or nearby (the Pirkanmaa region) were contacted and every person accepting the request was interviewed. Every biogas producer who could be reached was interviewed. The interviews with biodiesel producers were started from the producers who had presented their biodiesel activities in the media and then continued with the snowball method.
} 
make it an alternative to both an industrially minded productivist concept of agriculture and the post-productivist trajectories that have been presented as current alternatives for rural development (Marsden 2003; Wilson \& Rigg 2003; Mather et al. 2006).

The debate on multifunctionality has emerged in the global and conflictual context: the new era by integrating agriculture into the field of international negotiations on trade liberalization. Losch (2004) has identified four main currents that have moulded MF ideas and discussions. They are (1) The serious objections to the inherited productivist model of agricultural policy goals (2) The relation to an increasing environmental awareness (3) The demands of food security constituting one point of reference (4) The movement towards economic liberalization at the international level highlighting the scale of protection measured in the industrialized countries. As Garzon (2005; also Bjørkhaug \& Richards 2008) has noted, the concept of multifunctionality is of a normative and discursive nature. It has its roots in a social welfare justification for state assistance dating from the earliest years of the Common Agricultural Policy (Potter \& Tilzey 2005). The idea of multifunctionality can be understood as a counter narrative to the neoliberal vision for European agriculture that a more environmentally and socially specific version of farming has gained momentum in recent times and is promoted by a broad alliance of farmer and environmental groupings.

The advocates of multifunctionality have suggested that food production and environmental protection can be combined. This idea has also been linked to the defence of an exceptionalist "European model of agriculture" within the WTO. Thus, the multifunctionality scheme appears a positive characterisation, which recognises the continued importance of commodity production in rural areas (Losch 2004). It basically refers to all agricultural products, amenities and services created by farming activities to the benefit of the economy and to society as a whole. It aims to be sensitive to spatial and social differentiation and, therefore, it might provide a new foundation for public policies and a genuine paradigm change for farming. On the other hand, the basic idea behind agricultural multi-functionality is not new. As Pretty (2002; also McCarthy 2005) notes, agriculture is inherently multifunctional, since it jointly produces many unique non-food functions that cannot be produced by other economic sectors as efficiently.

The idea on multifunctionality figures in the debates on multilevel governance and postproductivism and, basically, it is applied to a wide range of locations and goals (e.g. Fouilleux 2004; Wilson 2008). As to the present rural development in general, policies have addressed lately not only the industrial efficiency of agriculture but also a more comprehensive stance including multifunctional rural livelihoods (Buller 2002). The strengthening of rural economy is associated with the introduction of new, non-agricultural enterprises (Ploeg et al. 2000). This may open up a new field for environmental-political and socio-economic innovations in the rural area not only on a local basis but also in the all-European interest.

Overall, multifunctionality aims to be a dynamic notion bringing together economic prosperity and environmental improvements. Consequently, rural policy for sustainability is not seen as a zero-sum game. Instead, it is strongly assumed that several goals can be realisable at one and the same time. From the environmental policy angle the notion comes close to the discourse of ecological modernisation, whose core elements cover environmental management and institutional greening (e.g. Marsden 2003; McCarthy 2005). As is known, ecological modernisation basically holds that economic development and environmental measures can be compatible and it also aims to integrate environmental policy with other policy sectors, especially those related to production (Berger et al. 2001; Holm and Stauning 2002; Jokinen et al. 2008).

\section{Sustainable livelihood and decision making at farms}

Sustainable development is a global policy discourse of origin (George 2007; Baker 2007). Yet, its emphasis is nowadays on the problems of implementation at different spatial scales (e.g. Meadowcroft 2007). To some extent, the implementation has been practically guided through Local Agenda 21 initiatives even if the results still leave a lot to be desired. Nevertheless, it is important that sustainable development is increasingly experimented at the local and regional scales. These experiments can inform local actors to take the challenge and responsibility to endorse both sustainable development and their own businesses. 
One way of understanding Local Agenda as a guide of implementation is to translate sustainable development into a social process which guarantees local actors the practical means of sustainable livelihood (e.g. Carney 1999; Tovey 2008). In the case of the recent rural development in Finland, this standpoint is quite well-founded: very few farms can take for granted the long-term sufficiency of their own farm assets when both the needs of business investment and family livelihood are considered.

According to Gibbs (2000) the definitions of sustainable development may vary but most of them allude to core principles such as

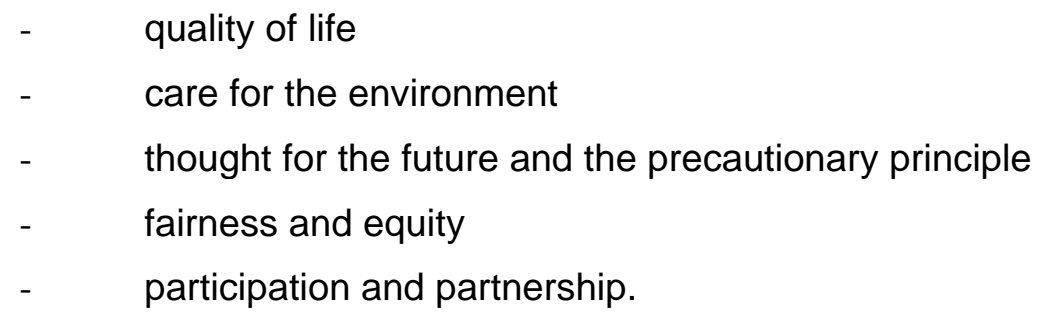

This list seems to capture the essential social dynamics in translating sustainable development into promotion of sustainable livelihood. Firstly, the guaranteed level of livelihood for the farmers' family is an asset for securing the stable quality of life which certainly is among the core targets of social sustainability (e.g. Baker 2006). The idea of quality of life can also be enriched through other aspects of livelihood such as improved professional skills or quality outdoor life at farm premises. Secondly, the care of the environment can be linked to sustainable livelihood through many practices of enhanced eco-efficiency embedded in the concepts of local food and renewable energy production (e.g. Marsden 2003). Thirdly, thought for the future and precaution are essential to both family farm resilience and to the larger local context in view of valuation of the local heritage. Fourthly, fairness and equity are related to the empowerment of both farming families and their local communities (e.g. Sage 2003). This is important in view of reciprocity to be enhanced at the local level but also in terms of cultural identity and cultural capital: they all can be considered as community assets for improved social resilience and sustainable livelihood. Finally, participation and partnership are essential in supporting the bottom-up type of governance (e.g. Morrison 2006).

Meeting the targets set above is not easy from the local perspective (e.g. Wallner 1999; Kinsella et al. 2000). Local communities vary a lot in their capacities to enhance sustainable development and livelihood for their inhabitants. An essential challenge is the depiction of the spatial and temporal "reclamations" from markets and the clarification of the way the products and services are presented as a brand for increased sustainability. It is most evident that farmers' decisions are greatly influenced by the market circumstances. Most of the food produced in Central Finland is consumed or processed in the nearby regions or, in any case, within the national boarders. Also renewable energy is often developed for serving local markets or local community and used mainly by private consumption on farms (see also van Vliet 2003). Thus, conquering local markets is perpetually at the core of the business planning.

Finally, we must identify the role of the state in facilitating or impeding farmers' decision of investing in locally sustainable production. Since the EU agriculture is still heavily supported by public sources, the farmers supposedly expect some supportive actions by the state or public authorities in general. If understood as a dynamic orientating principle for policy change, multifunctionality can support new, more localised food systems and energy systems and develop them seriously into existing arrangements. According to Kaljonen and Rikkonen (2004), the uncertain character of the CAP has strengthened the shared consensus in Finland, from local to national level, on the importance of domestic production. Thus, the notion of multifunctional agriculture can also be used as a rhetorical means for safeguarding the continuity of agriculture and recognising its societal value. 


\section{Local food production: cooperative effort for sustainable livelihood}

Local food system is primarily understood here as a spatial entity: it refers to a system of food provision where the physical and temporal distance between production, distribution and consumption is short (c.f. Feagan 2007). Local food activity has emerged fairly recently in Finland. In the present agricultural context, it is still a rather marginal phenomenon and its share of the total agricultural output is as yet very small. As in whole Finland, in our case area the number of farms is decreasing but the average size of production units is increasing. Hence, small-scale production seems to be seriously threatened in the pressure of market competition and the whole food system tends to develop into more centralised, intensified and specialised productions. On the other hand, even if large farms are more compatible with the current development, rural policy players have gradually acknowledged also the need to support localised food systems (e.g. MAF 2004). Besides the state, various NGO's (particularly consumer and environmental organisations) and sub-national actors (e.g. regional state policy authorities and municipalities) have become active in the very recent years. Interestingly, local food action in Finland can be seen as a particular mix of national policy and regional action where the food companies as well as individual farmers are often involved in. The action often takes shape in particular development projects.

The farmers we interviewed thought that they are, in fact, doing "something alternative" and most of them told that they had started producing local food much due to the present development of agriculture. Consequently, they did not want to do huge extensions or investments to revolutionize their traditional farming. Instead, they have searched for piecemeal strategies for keeping their farms viable. Many of them simply aim to safeguard the continuation of farming and to guarantee the basic family livelihood (Jokinen et al. 2008). However, these local food farms seem to have quite versatile nature as the farmers have many income sources. They usually still practice traditional farming but obtain additional income from secondary occupations such as selling local food products or doing some machinery work. Indeed, the number of diversified farms running not only agriculture and forestry but also other, nonagricultural business is increasing steadily. Nowadays more than a third of all Finnish farms count as diversified farms and, actually, this share is the highest among the EU27 countries (Niemi \& Ahlstedt 2008). In Central Finland around half of the all farms have other entrepreneurial activities besides agriculture and forestry (Niemelä et al. 2005).

Local food production is basically a significant way to diversify the basis of farm livelihood. In terms of sustainable livelihood, it seemingly appears beneficial to the farmers and their families. Yet, some interviewees thought that nowadays farms are carrying on already too many lines of production. A development manager argued that the unreasonable diversity in farming activities is obviously related to the basic cultural conception which orientates farmers to understand farming more in terms of a way of life than in actual business terms.

"When we started our counselling project with local farmers, some of them could not even tell us what their turnover was exactly. They acted like entrepreneurs but could not conceive their activity in terms of business operations." (Rural development manager)

When farm diversification, local food production, retails, networks, and rural development are addressed in general terms, it should also be thought how to make combinations with different products and services. Local food production could be combined, for instance, with rural tourism via guest house services or local restaurants. Until now there are not, however, many examples of this form of service supply in Central Finland.

The Finnish food retails are highly chained and, actually, a couple of major retailers dominate the whole market (e.g. Mononen \& Silvasti 2005). Therefore, small-scale entrepreneurs often find that their products are not taken by the chained suppliers. One of our major finding is that it is really important that local food producers develop networks with each other. A few of the producers we interviewed had already taken networking seriously and they were members of new cooperatives. One problem identified by the retailers is related to logistic solutions: the costs are undoubtedly lower if the food stuff is acquired from one wholesale actor, not from a number of small-scale suppliers. Furthermore, all retailers do not trust the local producers' ability to deliver products. 
"Any troubles on the farm affect us directly. When the supplier is a small-scale entrepreneur, every hassle or failure can cause great disturbance." (Retailer)

Importantly, by the networking farmers are able to expand production volume which, in turn, helps them in getting products to the retail. A new cooperative may also resolve the problem of the missing actor between the producers and the retailer. This is illustrated by a leading retailer in Central Finland ("Keskimaa", the Finnish name of the retailer) which has chosen to do local food business only with the local cooperative. It follows that farmers find the cooperative interesting and the reliability of deliveries is strengthened as well. Yet, a lot of social capital and trust is needed due to the multitude of contracts often based on oral agreements, for instance.

In order to be successful, local food production most probably will need also other types of networks in the future. According to our interviewees, small-scale entrepreneurs should find novel modes of co-operation with logistic and transport firms, for instance. Another form of networking which could support food production is the network between local producers and the large-scale food industry. The most advanced local food producers seem to have important visions on emerging local networks which utilise novel ideas and refine products on farms as a form of small-scale industrial production. Their main concern is how to extend the business into the processing of food without ending up in a complex jungle of regulations which they might not be able to handle without external professional help. We suggest therefore that public authorities increase their support and advocacy rather than prioritise the control of farming activities.

In sum, the production of local food seemingly has multifunctional dimensions since it emphasises the multiple value of agriculture in the regional framework. Firstly, in the local food system the supply chain is more transparent than is the case in the conventional production. Consequently, consumers are better informed about the whole food system in the case of local production. Secondly, local food adds to the overall social assets of a community through viable farming and also by means of multiplied networks and innovative forms of cooperation. Finally, from the view point of environmental governance, local food practices can provide important assets for managing rural landscape such as the maintenance of the landscape and the revitalisation of local heritage.

\section{Renewable energy production: networks supporting multifunctional agriculture}

Increasing fossil fuel prices and the climate change have given important push to the development of renewable energy technologies and also policies to facilitate their implementation (e.g. Huttunen 2009). Renewable energy has emerged swiftly at the top of the political agenda also in Finland and it is echoing particularly in the visions of rural policy (Mol 2007). Also interest in farm-based energy production has (re-)appeared (Hyttinen 2005; Åkerman et al. 2005). As concerns farm livelihood, it is important that the traditional multifunctionality on farms has been based on the combination of agriculture and forestry. Consequently, there are various alternatives for energy production regarding both energy sources. Farms themselves need electricity, heat, and fuels for transportation and machinery. They can also produce energy for sale. There are various means to meet the energy needs depending on the natural resources and production type in the farm. Typically farms can utilize wood from the forests owned by the farmer, host wind turbines or water turbines in the case of the suitable watercourse, or cultivate energy crops and produce biogas from animal manure and other organic residues. Basically, the farmer can produce and sell the energy directly or she can produce raw material such as wheat or reed canary grass which can be used in energy production by others. In any case, there are various stakeholders included and networks need to be established. The farmer seldom produces energy alone but forms a co-operative with some or several other farmers. The operation model of the on-farm energy production is presented in Figure 1. 


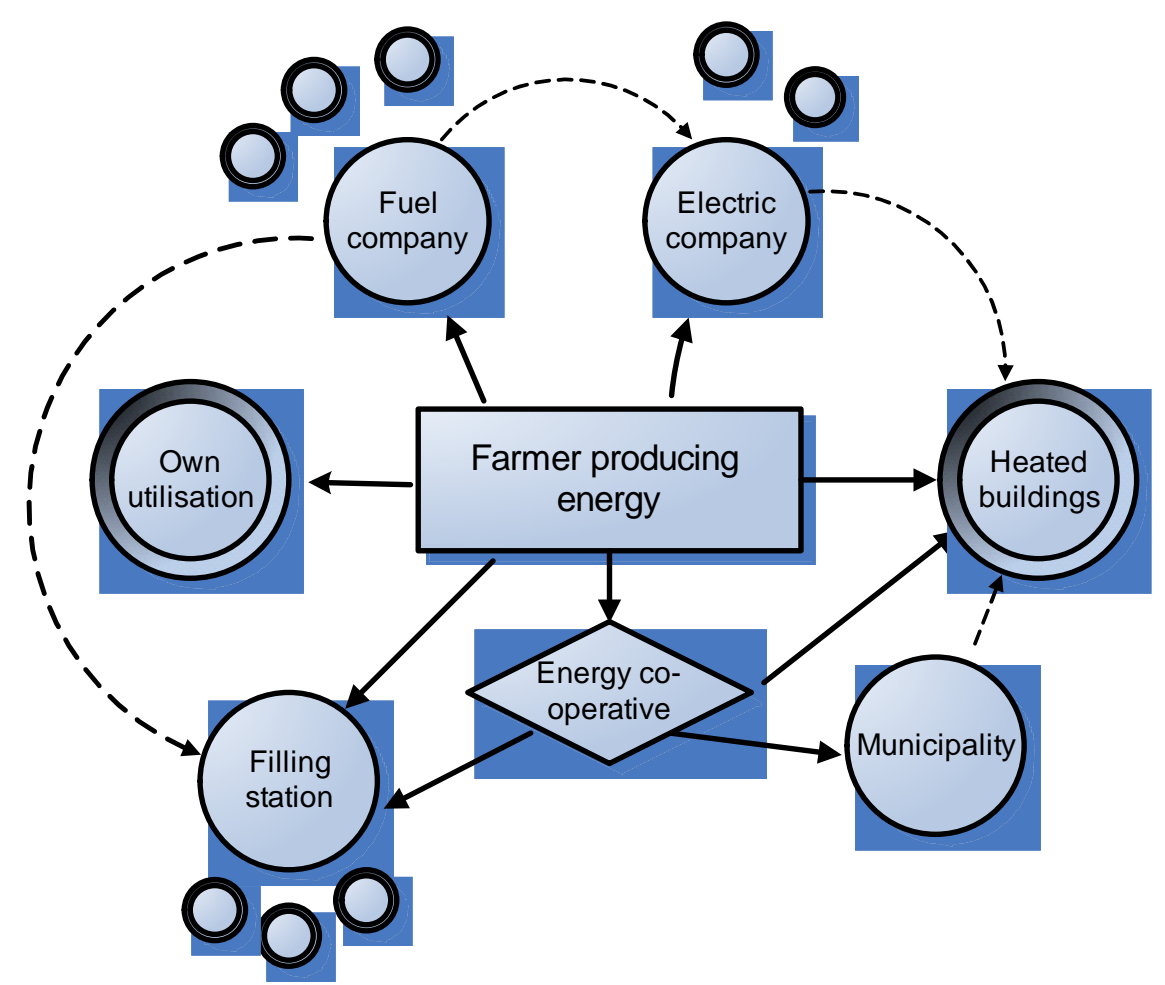

Fig 1. The operation model and stakeholders in farm-scale energy production

Heat entrepreneurship, emerged during the last fifteen years, is the most common model of renewable energy production in Finnish farms. Heating entrepreneurship creates varying local actor networks consisting of the providers of fuel (e.g. forest owners, wood procurer, transporter, chipping/sawmill operator), operators of the boiler, and the customers. It is a form of providing heat mainly to large estates by utilising local wood fuels. The entrepreneur produces the fuel from her or his own forest or buys it from other local forest owners or from the local wood processing industry. She or he provides the fuel for the heating site and carries out the heating, operation and maintenance at the heating plant. The entrepreneur is paid on the basis of the amount of heat generated. Importantly, wood fuel production is integrated into other rural production practices such as farming, family forestry or logging contracting and it is thus based on the use of existing harvesting or agricultural machinery.

The heat entrepreneurs we interviewed expressed various reasons for the energy production, depending on the scale and economic importance of their activity. The basic reason is the need for extra income source since farming is not profitable enough. The demands for farming changed after Finland had joined the EU and heat entrepreneurship really is a viable alternative to provide the needed income.

"Nowadays everything in the countryside is because of EU. Our milk production was so low that we were forced to either end it or expand it. After 30 years of milking, I thought it was enough. After switching to meat and grain production I had more time and needed to start looking for other businesses." (Male farmer and heat entrepreneur, working alone)

Heat entrepreneurship can provide up to half of the farmer's income although for some farmers it is just a hobby and something to be interested in. Farmers have also minor reasons for their heat production. For instance, some want to promote domestic energy production because they are concerned of the depletion of fossil fuels. These concerns relate to the rhetoric of wood energy promoters and they were also used as an argument presenting heat entrepreneurship as an important and positive activity. The occupation was also considered important due to silvicultural reasons and forestry activities.

"Well, heat entrepreneurship started from that it is patriotic as we have raw material in Finland and it can be an instrument to employ a lot of people." (Male farmer and heat entrepreneur in a consortium) 
"It started from the first thinning - how could we make good use of the thinned waste wood?" (Male farmer and heat entrepreneur in a consortium)

Heat entrepreneurship has important effects on the farmers' lives. It might have enabled the existence of quite a small farm and thus the livelihood in the countryside. It can also enhance farmers' social networking although typically the co-operative partners had been known before the co-operation was established. The increased dealings with each other deepen acquaintances even into friendships. Co-operative work differs from farmers' normal work where they often carry the heavy responsibilities of the functioning of the farm alone. The new shared responsibility was found as a relieving and easing factor.

"It has increased activities and collaboration and dealings with these people have increased. It has also other meanings than just the financial one." (Male farmer and heat entrepreneur in a consortium)

"Of course this is our gang; this is great compared with my own work (farming), because here you are never alone. When you are unable to do something there is always someone else who can do it. So this is mentally easy, if something comes up it isn't just you who is responsible." (Male farmer and heat entrepreneur in a consortium)

The local area benefits from the entrepreneur activity as employment increases and the farmers are more fully employed. Also local harvesting entrepreneurs gain more working opportunities (c.f. Akkerman et al. 2005). Besides the employment effect, heat entrepreneurship intensifies forestry: thinning in the young forests becomes feasible due to the stumping price paid by the small-scale entrepreneurs compared to more industrial businesses.

"At the local level, it helps that there is a local actor at the energy sector who is able to pay better price (of waste wood material) than the large industrial actors who in practice pay nothing." (Male farmer and heat entrepreneur in a consortium)

Moreover, replacing fossil fuels with renewable bioenergy reduces carbon dioxide emissions. This is an important function of heat entrepreneurship. However, it is not self-evident to the entrepreneurs. They are varyingly concerned of environmental issues such as climate change but paradoxically they seem to think that individuals cannot do anything to prevent it and they do not draw connection between their own entrepreneurship and climate change. They are more worried of the negative environmental impacts their plant might have in terms of soot and smoke.

Heat entrepreneur: "I'm not more concerned of environmental issues than an ordinary farmer is. I think my livelihood is very close to nature, taking care of forests and..."

Interviewer: "What about climate change?"

Heat entrepreneur: "I think it is a global issue, there is not much an individual can do about it."

(Male farmer and heat entrepreneur in a consortium)

\section{Conclusions}

It seems evident that some new dynamics of sustainable rural development is emerging in Central Finland. Both local food production and heat entrepreneurship have several important functions in the rural areas. Much of the pioneering entrepreneurship starts out because the traditional agricultural activities do not guarantee the continuation of farming anymore and new business ideas are needed. One of the encouraging visions is that farm livelihood will be maintained for the next generation by investing in new products or even in the new production methods and refinement of products on farms.

A clear indication of the current social transformation is that individual farms begin to identify the importance of mutual networking while finding their way of establishing new businesses that will meet a variety of sustainability criteria. This entails not only the important socio-economic transition as related to both local food system and renewable energy delivery but also an element of socio-cultural change that encourages mutual trust and social capital. In the Finnish case, the latter is a remarkable new feature since the main trend of rural development has reduced rural population and resulted in a certain isolation of individual farms. The producers of 
renewable energy emphasised the positive impacts of networking whereas networking seemed to be somewhat more challenging for the local food producers due to the high diversity of products, difficult access to retails and even due to cultural reasons such as the individualising business tradition. Nevertheless, both production branches we addressed are taking important steps towards the cooperation of local actors.

Our empirical results suggest that farmers in Central Finland seldom go for very radical alternative productions imitating strong ecological modernisation. Rather, their "cautionary principle" is consistent with a weak version of ecological modernisation adjusting to the mainstream greening of consumption. There are, however, signs of targeting towards sustainable business in a broader variety. The strong versions of ecological modernisation obviously apply to renewable energy production and especially to new energy crops or to other electricity productions still appearing more as plans than on-going productions.

A further challenge for farmers' livelihood and local sustainability is the complexity of local networks. It is important that the producers find ways of mutual cooperation but it seems equally important to upscale networking along the whole value chain towards the end-users. Details of the operative models may differ between local food producers and renewable energy producers. However, both groups have to solve the problems related to the logistics, wholesale, the access to the market, and the reliability of delivery. It obviously demands social innovation through the means of co-operation and networks. According to an optimistic view, the farmers solve most of these problems by their own activity. On the other hand, public policy could be helpful on condition that farmers are left with reasonable space for self-governance. An alternative view is to assume a most supportive action for multifunctionality at the regional level (c.f. Dufour et al. 2007). In that case, multifunctionality needs to be upgraded first to the community level for enhancing the sustainable livelihood pursuit and sustainability of on-farm activities.

References

[1] ÅKERMAN, M., KALJONEN, M. \& PELTOLA, T. (2005). Integrating Environmental Policies into Local Practices: The Politics of Agri-environmental and Energy Policies in Rural Finland. Local Environment 10(6), 595-611.

[2] ALANEN, V. (2007). Lämpöyrittäjätoiminta 2006. Työtehoseura.

[3] BAKER, S. (2006). Sustainable development. London: Routledge.

[4] BAKER, S. (2007). Sustainable development as symbolic commitment: Declaratory politics and the seductive appeal of ecological modernisation in the European Union. Environmental Politics 16(2), 297-317.

[5] BERGER, G., FLYNN, A., HINES, F. \& JOHNS, R. (2001). Ecological modernization as a basis for environmental policy: current environmental discourse and policy and the implications on environmental supply chain management. Innovation 14(1), 55-72.

[6] BJØRKHAUG, H. \& RICHARDS, C. (2008). Multifunctional agriculture in policy and practice? A comparative analysis of Norway and Australia. Journal of Rural Studies 24(1), 98-111.

[7] BLAKE, J. (1999). Overcoming the 'value-action gap' in environmental policy: tensions between national policy and local experience. Local Environment 4(3), 257-278.

[8] BULLER, H. (2002), Integrating European Union environmental and agricultural policy. In Lenschow, A. (Ed.), Environmental Policy Integration (pp. 103-126). London: Earthscan.

[9] CARNEY, D. (1999): Approaches to sustainable livelihoods for the rural poor. Overseas Development Institute. Retrieved September 30, 2008. from:

http://www.odi.org.uk/resources/specialist/poverty-briefings/2-sustainable-livelihoods-ruralpoor.pdf

[10] DUFOUR, A., MAUZ, I., RÉMY, J., BERNARD, C., DOBREMEZ, L., HAVET, A., PAUTHENET, Y., PLUVINAGE, J. \& TCHAKÉRIAN, E. (2007). Multifunctionality in agriculture and its agents: regional comparisons. Sociologia Ruralis 47(4), 316-342. 
[11] ELLIOTT, D. (2000). Renewable energy and sustainable futures. Futures 32(3), 261-274.

[12] FEAGAN, R. (2007). The place of food: mapping out the "locals" in local food systems. Progress in Human Geography 31(1), 23-42.

[13] FONTE, M. (2008). Knowledge, food and place. A way of producing, a way of knowing. Sociologia Ruralis 48(3), 200-222.

[14] FOUILLEUX, E. (2004). CAP reforms and multilateral trade negotiation: Another view on discourse efficiency. West European Politics 27(2), 235-255.

[15] GARZON, I. (2005). Multifunctionality of agriculture in the European Union: Is there substance behind the discourse's smoke? UC Berkeley: Center on Institutions and Governance.

[16] GEORGE, C. (2007). Sustainable development and global governance. The Journal of Environment \& Development 16(1), 102-125.

[17] GIBBS, D. (2000). Ecological modernisation, regional economic development and regional development agencies. Geoforum 31(1), 9-19.

[18] HALKIER, B., HOLM, L., DOMINGUES, M., MAGAUDDA, P., NIELSEN, A. \& TERRAGNI, L. (2007). Trusting, complex, quality conscious or unprotected? Constructing the food consumer in different European national contexts. Journal of Consumer Culture 7(3), 379-402.

[19] HOLM, J. \& STAUNING, I. (2002). Ecological modernisation and "Our Daily Bread". Variations in the transition of the food sector. The Journal of Transdisciplinary Environmental Studies 1(1), 1-13.

[20] HUTTUNEN, S. (2009). Ecological modernisation and discourses on rural non-wood bioenergy production in Finland from 1980 to 2005. Journal of Rural Studies 25. (in press)

[21] HYTTINEN, T. (2005). Valoa pimeässä. Kohti energiaomavaraisuutta maaseudulle. Vaasa: Vaasan yliopisto.

[22] JOKINEN, P., JÄRVELÄ, M., HUTTUNEN, S. \& PUUPPONEN, A. (2008). Experiments of sustainable rural livelihood in Finland. International Journal of Agricultural Resources, Governance and Ecology 8(3), 211-228.

[23] KALJONEN, M. \& RIKKONEN, P. (2004). Divergent images of multifunctional agriculture: A comparative study of the future images between farmers and agri-food experts in Finland. International Journal of Agricultural Sustainability 2(3), 190-204.

[24] KINSELLA, J., WILSON, S., DE JONG, F. \& RENTING, H. (2000). Pluriactivity as a livelihood strategy in Irish farm households and its role in rural development. Sociologia Ruralis 40(4), 481-496.

[25] KUITTINEN, V., HUTTUNEN, M. \& LEINONEN, S. (2007). Suomen biokaasulaitosrekisteri 10. Joensuu: Joensuun yliopisto.

[26] LOSCH, B. (2004). Debating the multifunctionality of agriculture: From trade negotiations to development policies by the South. Journal of Agrarian Change 4(3), 336-360.

[27] LYONS, K., BURCH, D., LAWRENCE, G. \& LOCKIE, S. (2004). Contrasting paths of corporate greening in Antipodean agriculture: organics and green production. In Jansen, $\mathrm{K}$. \& Vellema, S. (Eds.), Agribusiness \& Society (pp. 91-113). New York: Zed Books.

[28] MARSDEN, T. (2003). The condition of rural sustainability. Wageningen: Van Gorcum.

[29] MATHER, A.S., HILL, G. \& NIJNIK, M. (2006). Post-productivism and rural land use: Cul De Sac or challenge for theorization? Journal of Rural Studies 22(4), 441-455.

[30] MCCARTHY, J. (2005). Rural geography: multifunctional rural geographies - reactionary or radical? Progress in Human Geography 29(6), 773-782.

[31] MEADOWCROFT, J. (2007). National sustainable development strategies: features, challenges and reflexivity. European Environment 17(3), 152-163 
[32] MINISTRY OF AGRICULTURE AND FORESTRY (2004). Viable countryside - our joint responsibility. Finnish Rural Policy Programme 2005-2008. Helsinki: MAF

[33] MINISTRY OF THE INTERIOR (2007). Viable countryside - ministerial responsibilities and regional development. Helsinki: Edita.

[34] MONONEN, T. \& SILVASTI, T. (Eds.) (2005). Ruokakysymys. Näkökulmia yhteiskuntatieteelliseen elintarviketutkimukseen. Helsinki: Gaudeamus.

[35] MORGAN, K., MARSDEN, T. \& MURDOCH, J. (2006). Worlds of food. Place, power, and provenance in the food chain. Oxford: Oxford University Press.

[36] MORRISON, T.H. (2006). Pursuing rural sustainability at the regional level: Key lessons from the literature on institutions, integration, and the environment. Journal of Planning Literature 21(2), 143-152.

[37] NIEMELÄ, T., HEIKKILÄ, E. \& MERILÄINEN, T. (2005). Monialainen yritystoiminta KeskiSuomen maatiloilla. Jyväskylä: Jyväskylän yliopisto.

[38] NIEMI, J. \& AHLSTEDT. J. (Eds.) (2008). Finnish agriculture and rural industries 2008. Helsinki: Agrifood Research Finland.

[39] NIEMINEN, A. (Ed.) (2006). Development programme for the food sector in Central Finland, years 2007-2013. Jyväskylä: Jyväskylä University of Applied Sciences.

[40] PLOEG, VAN DER J., RENTING, H., BRUNORI, G., KNICKEL, K., MANNION, J., MARSDEN, T., DE ROEST, K., SEVILLA-GUZMÁN, E. \& VENTURA, F. (2000). Rural development: From practices and policies towards theory. Sociologia Ruralis 40(4), 391-408.

[41] POTTER, C. \& TILZEY, M. (2005). Agricultural policy discourses in the European postFordist transition: neoliberalism, neomercantilism and multifunctionality. Progress in Human Geography 29(5), 581-600.

[42] PRETTY, J. (2002). Agri-culture. Reconnecting people, land and nature. London: Earthscan.

[43] SAGE, C. (2003). Social embeddedness and relations of regard: Alternative "Good Food" networks in South-West Ireland. Journal of Rural Studies 19(1), 47-60.

[44] SILVASTI, T. (2003). The cultural model of "the Good Farmer" and the environmental question in Finland. Agriculture and Human Values 20(2), 143-150.

[45] TOVEY, H. (2008). Rural sustainable development in the knowledge society era. Sociologia Ruralis 48(3), 185-199.

[46] TYKKYLÄINEN, M. (2005). Spatial restructuring of rural Finland. In Schied, D. (Ed.), Winning and losing, the changing geography of Europe's rural areas (pp. 265-280). Aldershot: Ashgate

[47] VAN VLIET, B. (2003). Differentiation and ecological modernization in water and electricity provision and consumption. Innovation 16(1), 29-49.

[48] WALLNER, H. (1999). Towards sustainable development of industry: networking, complexity and eco-clusters. Journal of Cleaner Production 7(1), 49-58.

[49] WILSON, G. (2008). From "weak" to "strong" multifunctionality: Conceptualising farm-level multifunctional transitional pathways. Journal of Rural Studies 24(3), 367-383.

[50] WILSON, G. \& RIGG, J. (2003). "Post-productivist" agricultural regimes and the South: Discordant concepts? Progress in Human Geography 27(6), 681-707. 